\title{
Available but irrelevant: when and why information from memory hinders diagnostic reasoning
}

Citation for published version (APA):

de Bruin, A. B. H., Camp, G., \& van Merrienboer, J. J. G. (2010). Available but irrelevant: when and why information from memory hinders diagnostic reasoning. Medical Education, 44(10), 948-950. https://doi.org/10.1111/j.1365-2923.2010.03789.x

Document status and date:

Published: 01/10/2010

DOI:

10.1111/j.1365-2923.2010.03789.x

Document Version:

Publisher's PDF, also known as Version of record

Document license:

Taverne

Please check the document version of this publication:

- A submitted manuscript is the version of the article upon submission and before peer-review. There can be important differences between the submitted version and the official published version of record.

People interested in the research are advised to contact the author for the final version of the publication, or visit the DOI to the publisher's website.

- The final author version and the galley proof are versions of the publication after peer review.

- The final published version features the final layout of the paper including the volume, issue and page numbers.

Link to publication

\footnotetext{
General rights rights.

- You may freely distribute the URL identifying the publication in the public portal. please follow below link for the End User Agreement:

www.umlib.nl/taverne-license

Take down policy

If you believe that this document breaches copyright please contact us at:

repository@maastrichtuniversity.nl

providing details and we will investigate your claim.
}

Copyright and moral rights for the publications made accessible in the public portal are retained by the authors and/or other copyright owners and it is a condition of accessing publications that users recognise and abide by the legal requirements associated with these

- Users may download and print one copy of any publication from the public portal for the purpose of private study or research.

- You may not further distribute the material or use it for any profit-making activity or commercial gain

If the publication is distributed under the terms of Article $25 \mathrm{fa}$ of the Dutch Copyright Act, indicated by the "Taverne" license above, 


\section{REFERENCES}

1 Holy Bible, New International Version. Proverbs 12: 15. Colorado Springs, CO: Biblica 1984.

2 Regehr G. It's NOT rocket science: rethinking our metaphors for research in health professions education. Med Educ 2010;44:31-9.

3 Durning SJ, Artino A, Boulet J, van der Vleuten CPM, La Rochelle J, Arze B, Schuwirth L. Making use of contrasting participant views of the same encounter. Med Educ 2010;44:953-61.

4 Schuwirth LW, van der Vleuten CP. A plea for new psychometric models in educational assessment. Med Educ 2006;40:296-300.

5 Crossley J, Roberts C, Jolly B, Humphries G, Ricketts C, Norcini J, Schuwirth L. 'I'm pickin' up good regressions': the governance of generalisability analyses. Med Educ 2007;41:926-34.
6 Beard JD, Purdie H, Marriott J, Crossley J. Assessing the surgical skills of trainees in the operating theatre: a prospective observational study. HTA J Ser 2010 (in press).

7 Holmboe ES, Hawkins RE, Huot SJ. Effects of training in direct observation of medical residents' clinical competence: a randomised trial. Ann Intern Med 2004;140:87481 .

\title{
Available but irrelevant: when and why information from memory hinders diagnostic reasoning
}

\author{
Anique B H de Bruin, ${ }^{1,2}$ Gino Camp ${ }^{2} \&$ Jeroen J G van Merriënboer ${ }^{1}$
}

Doctors are not computers, fortunately. They don't calculate risks weighting patient information equally, stating diagnoses with a non-negotiable and carefully computed level of probability. Instead, doctors are humans. They possess limited working memory capacity to process the information they receive from patients, ${ }^{1}$ they have to work with rapidly changing circumstances, and they are required to make decisions under suboptimal conditions. In any presentation of patient informa-

\footnotetext{
${ }^{1}$ Department of Education Development and Research, Maastricht University, Maastricht, the Netherlands

${ }^{2}$ Department of Psychology, Erasmus University Rotterdam, Rotterdam, the Netherlands

Correspondence: Anique B H de Bruin, Department of Educational Development and Research, Faculty of Health, Medicine, and Life Sciences, P.O. Box 616, 6200 MD, Maastricht, the Netherlands. Tel: +31 43 3885773; Fax: +31 43 3885779;

E-mail: anique.debruin@educ.unimaas.nl
}

doi: 10.1111/j.1365-2923.2010.03789.x tion, each symptom may open up a multitude of possible diagnoses, and computing the correct diagnosis is a task the human mind cannot approach by considering each possibility. Through evolution our brains have adapted to solve such complex tasks and we have learned to develop and implement heuristics, also known as 'rules of thumb' or cognitive shortcuts, to guide our decision making. Evidence that these cognitive shortcuts benefit diagnostic reasoning is underlined by the observation that computers, apart from a handful of exceptions, have great difficulty in matching the diagnostic performance of doctors and that intelligent software usually mimics the heuristic reasoning strategies used by doctors. ${ }^{2}$ It is important to note, as do Wegwarth et al., ${ }^{3}$ that these heuristics are not just the result of the constraints of human working memory, but are also used because the information available is always limited, which renders future outcomes uncertain and the solution to the problem incomputable.

\section{Evidence that cognitive shortcuts benefit diagnostic reasoning is underlined by the observation that intelligent software usually mimics the heuristic reasoning strategies used by doctors}

So how should doctors approach diagnostic reasoning given that the resources available to them, both externally and internally, may be severely limited? Marewski et al. ${ }^{4}$ advocate what they term 'ecological rationality'. Given the sparse resources that we humans are faced with, we need to rely on cognitive shortcuts. That is to say, our rationality is bounded. ${ }^{5,6}$ However, the heuristics we apply are not universal, all-or-none phenomena. Individuals develop these so as to fit the structure of the environment, which make them highly specialised for specific tasks in specific circumstances. In a similar vein, experienced doctors possess highly evolved heuristics within their area of specialty that allow them to reason flexibly and to the best of their ability. Recent studies have even emphasised the finding that 
doctors perform better when they process less information. ${ }^{7}$

Heuristics are also used because the information available is limited, future outcomes are uncertain and the solution to the problem incomputable

As the article in this issue by Mazzocco and Cherubini ${ }^{8}$ clearly points out, the story unfortunately does not end here. The authors show in a carefully controlled experimental set-up a potential drawback of the use of heuristics. Their results reveal that $39 \%$ of experienced doctors and $56 \%$ of experienced nurses changed their diagnosis on a novel but similar case when confronted with an aversive outcome on a previously diagnosed case. This phenomenon is the result of a wrongfully applied heuristic and leads to what is termed 'outcome bias'. ${ }^{9}$ Obviously, it is undesirable that, based on a single case experience, doctors and nurses ignore their entire knowledge base and change their clinical diagnosis.

To shed light on these findings, it is useful to elaborate on a specific characteristic of human memory. To compensate for limited capacity, human memory facilitates the remembering of recently encountered or salient information under the assumption that what

happened a short time ago, or what left a large impression on the rememberer, is relevant to retrieve. The latter situation is considered adaptive in medical decision making: a salient error will lead a doctor to more careful screening for certain diagnoses in the future. By contrast, the former situation is generally considered maladaptive in clinical reasoning and leads to availability bias, or the situation in which information that was stored recently is easily retrieved from memory and thereby exerts an

exaggerated influence on decision making. ${ }^{10}$ One can imagine that in other situations this memory mechanism is very useful (e.g. when searching for your car keys). However, in medical decision making, availability bias should be avoided as the better diagnosis is always the one that is based on the doctor's entire knowledge base rather than the one that is overshadowed by the most recent experience. Outcome bias could be considered a special case of availability bias in that a recent, salient, although irrelevant, experience (negative outcome) dominates memory and thus diagnostic reasoning for a certain amount of time. Awareness of how and when it occurs and its aversive effects should be fostered among doctors and medical students.

Human memory facilitates the remembering of recently encountered information under the assumption that what happened a short time ago is relevant to retrieve

The well-controlled experiment run by Mazzocco and Cherubini ${ }^{8}$ allows for a number of relevant experimental extensions that will provide insight into the scope of this type of availability bias as they sketch it. Firstly, it is interesting to assess the duration of bias in a naturalistic setting. Does the effect hold for a number of hours, days or weeks? Or does it hold until the next patient with a similar pattern of symptoms presents, regardless of elapsed time? An answer to this question is crucial to determine the extensiveness of availability bias in everyday clinical reasoning.

Moreover, varying the similarity between cases both superficially and structurally is useful to examine how sensitive doctors' reasoning is to this bias. That is, what degree of overlap between patient symptoms is minimally required for availability bias to occur? Finally, these questions can be supplemented with the effect of expertise in the same experiment. Does the bias diminish as experience grows? Does the effect of similarity between cases depend on experience?

In medical decision making, the better diagnosis is always based on the doctor's entire knowledge base rather than being overshadowed by recent experience

How do doctors recover from possible aversive effects of heuristics? Recent research by Mamede $e t$ al. ${ }^{11}$ shows that doctors do so as adaptively as they use these heuristics. These researchers asked residents in internal medicine to study a number of simple and complex clinical cases under one of three instructions. Participants stated a diagnosis either immediately after studying the case or after working on an unrelated distracter task (solving word puzzles) for several minutes, or were asked to evaluate their diagnosis in light of the evidence and decide upon a final diagnosis afterwards. For complex cases, the latter instruction of what they termed 'conscious thought' led to the best diagnostic decisions. For simple cases, even the immediate decisions led to good diagnoses and consciously thinking about them did not improve them. This leads us to conclude that the use of heuristics is justified in routine diagnostic reasoning and, when faced with a complex case, a relatively simple instruction of consciously thinking about the evidence for a diagnosis before coming to a final conclusion can prevent heuristic errors. In itself, the flexible use of either heuristic or conscious reasoning depending on case complexity could be called a case-approach heuristic that experienced doctors should be aware of and that 
students should learn to apply in clinical practice.

\section{REFERENCES}

1 Miller GA. The magical number seven, plus or minus two: some limits on our capacity for processing information. Psychol Rev 1956;63:81-97.

2 Lucas PJF, de Bruijn NC, Schurink $\mathrm{K}$, Hoepelman A. A probabilistic and decision-theoretic approach to the management of infectious disease at the ICU. Artif Intell Med 2000;19 (3):251-79.

3 Wegwarth O, Gaissmaier W, Gigerenzer G. Smart strategies for doctors and doctors-in-training: heuristics in medicine. Med Educ 2009;43:721-8.

4 Marewski JN, Gaissmaier W, Gigerenzer G. Good judgements do not require complex cognition. Cogn Process 2010;11 (2):103-21.

5 Simon HA. Rational choice and the structure of the environment. Psychol Rev 1956;63:129-38.

6 Simon HA. Invariants of human behaviour. Annu Rev Psychol 1990;41:1-19.

7 Reyna VF, Lloyd FJ. Physician decision making and cardiac risk: effects of knowledge, risk perception, risk tolerance, and fuzzy processing. J Exp Psychol Appl 2006;12 (3):179-95.
8 Mazzocco K, Cherubini P. The effect of outcome information on health professionals' spontaneous learning. Med Educ 2010;44:962-8.

9 Baron J, Hershey JC. Outcome bias in decision evaluation. $J$ Pers Soc Psychol 1988;54:569-79.

10 Tversky A, Kahneman D. Availability: a heuristic for judging frequency and probability. $\operatorname{Cog} n$ Psychol 1973;5:207-32.

11 Mamede S, Schmidt HG, Rikers RMJP, Custers EJFM, Splinter TA, van Saase JLCM. Conscious thought beats deliberation without attention in diagnostic decision making: at least when you are an expert. Psychol Res (in press).

\section{Stress and learning}

\section{Charles B Kromann, Morten L Jensen \& Charlotte Ringsted}

Most of us have discovered that otherwise readily available memories can be impossible to retrieve in stressful situations. Somehow, the harder you work at remembering something, the more annoyingly impossible it is to do so. Later, in a more relaxed setting, the volatile piece of information suddenly pops up without the slightest effort. This situation corresponds with the general impression that stress is detrimental to memory retrieval, an impression that is supported by neurobiological trials of the effects of arousal and stress hormones. ${ }^{1,2}$ Furthermore, a chronic high stress level is known to have an impact on both physical

\footnotetext{
Copenhagen, Denmark

Correspondence: Charles B Kromann, Centre for Clinical Education, Rigshopitalet Afsnit 5404, Blegdamsvej 9, DK-2100 KBH $\varnothing$, Denmark. Tel: 00454244 2905; Fax: 00453545 4437;

E-mail: charles.kromann@gmail.com
} doi: 10.1111/j.1365-2923.2010.03817.x and mental health. ${ }^{3}$ However, there is also a common belief that a little bit of stress can boost a learning process. In the military, in aviation and, certainly, also in medical simulation, stress has intuitively been added to learning situations in order to increase learning outcome. ${ }^{1}$

In this issue of Medical Education, the paper 'Adding emotional stressors to an ACLS course enhances participant performance in a simulated cardiopulmonary arrest' argues that we should deliberately use stressors as part of teaching in order to promote long-term learning outcome. ${ }^{4}$ By contrast, the paper 'The Medical Student Stress Profile: a tool for stress audit in medical training' proposes that we should consider individualised stress regulation in medical students in order to promote effective learning and health. ${ }^{5}$ It is pertinent for medical educators at all levels to consider the learning environment for their medical students and junior doctors at all times.
In the military and in aviation, stress has intuitively been added to learning situations in order to increase learning outcome

DeMaria et $a l .{ }^{4}$ demonstrate that emotional stress applied in controlled simulations in a context relevant to and congruent with the subject of the simulation has the effect of enhancing resuscitation skills learning. Two groups of medical students went through similar courses. The only element that differed was how the actors behaved during the simulation scenarios. In the intervention group, the actors' behaviour was problematic and emotional: the nurses argued; the interns and relatives panicked. In the control group, the actors were subservient or helpful. During the simulationbased training, the intervention group was measurably more stressed than the control group. An assessment of long-term learning outcome 6 months after the course 